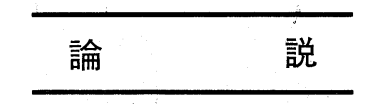

頭 蓋 底 外 科

一前頭蓋底の腫瘍に対する手術を中心に一

平野実

\title{
Surgery of the Skull Base
}

\author{
-A Tutorial Note- \\ Minoru Hirano \\ (Kurume University)
}

Advances in surgery of the skull base have greatly benefited patients with neoplasms of this area which had been unresectable until recently. This paper describes the concept of surgery of the skull base, the surgical anatomy of the skull base and the techniques of craniofacial resection. An interdisciplinary team that consists of an otolaryngologist, a neurosurgeon and a plastic surgeon is essential for craniofacial resection. It should be emphasized that the skull base is now accessible surgically. Unfortunately, the number of otolaryngologists who perform surgery of the skull base seems to be limited in Japan. Otolaryngologists working in major medical centers are strongly encouraged to pay attention to surgery of the skull base.

Key words: surgery of the skull base, craniofacial resection, anatomy of skull base

はじめに

頭蓋底外科 (surgery of the skull base) とは “頭蓋底とその周辺の病変を対象とする外科”之 定義される，乙のような範鋳に入る手術には， 随分古くから行われているあのあある。たとえ ば，1952年発行の日本耳鼻咽喉科全書 ${ }^{1}$ に記さ れている手術のうちで, $\mathrm{S}$ 状静脈洞血栓, 錐体 尖炎, 耳性脳膿瘍, 耳性脳膜炎, 聴神経腫瘍な どに対する手術は，まさに頭蓋底外科に属する あのである，乙れらの手術の源はさらに古く今 世紀の初め，あるいはそれ以前にさかのぼる.
近年，頭蓋底外科という概念が打ち出され， 関連する外科医達の注目を集め始め, それに関 する著書や論文が増えつつある。我国であ昨年, 日本頭蓋底外科研究会が組織され, 毎年学術講 演会が行われ始めた。 このような頭蓋底外科と (う概念の発達とその手技の発展は，1）手術 技術の進歩，と2）異なる専門家達のチーム・ アプローチ，によるところが大きい、私達耳鼻 咽喉科 - 頭頸部外科医は, 脳神経外科医, 形成 外科医とともに頭蓋底外科チームの柱となる専 門医である. 
私達の教室では，1984年に脳神経外科，形成 外科の専門医達とチームを組織した，以来，そ れより前から行っていた側頭骨関連の頭蓋底外 科，経蝶形洞下垂体手術など，耳鼻咽喉科・頭 頸部外科医だけでできる手術に加えて，チーム ・アプローチによる頭蓋底外科のレパートリを 拡げつつある.

私達の経験は未だ少なく，論説を書くのは少 少おてがましいが，現今急速に発展しつつある 外科学の重要な分野に, 一人でも多くの方達が
目を向け，取り組んでいただきたいと願い，乙 の稿を書く次第である.

\section{頭蓋底の解剖の概要}

頭蓋底は前，中，後の 3 つの部分に分けられ る(図 1 ).

前頭蓋底は前頭洞，篩骨洞，鼻腔嗅裂，眼窩 と骨一枚を介して接する。正中部の中央に嗅神 経が通る節板が，後端で中頭蓋底との境界部に 視神経管がある．前頭開頭下に前頭葉を挙上し ていくと，視神経交叉まで明視下におくことが

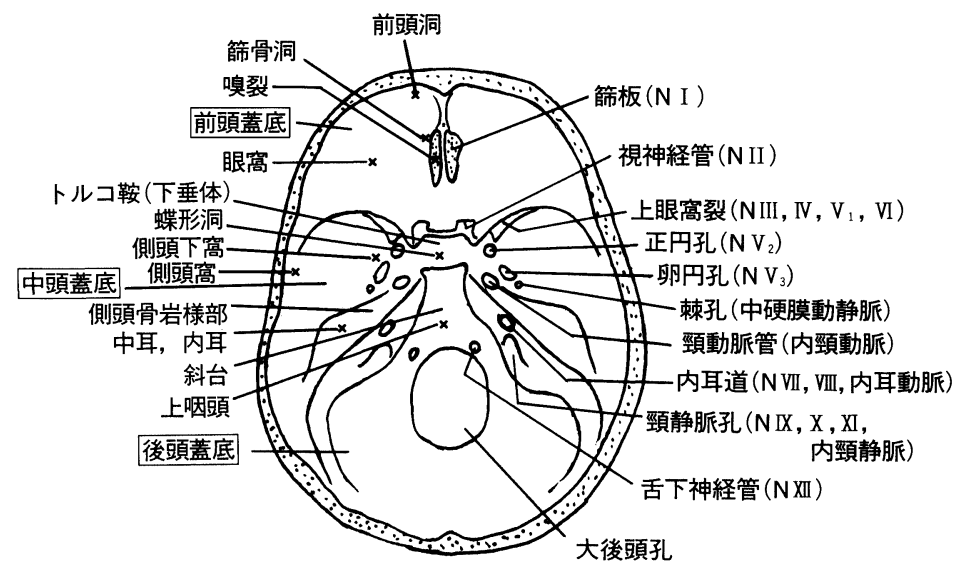

A：頭蓋内面（上面）

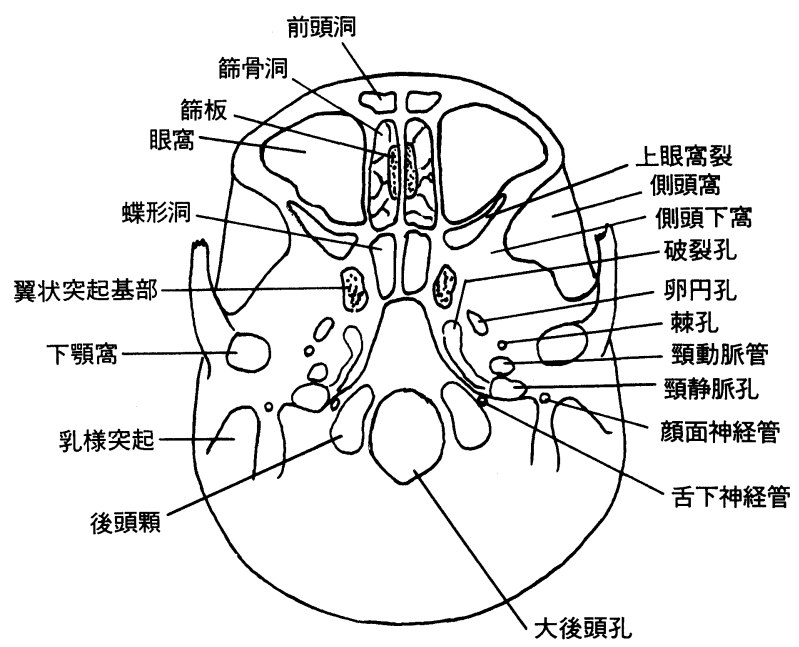

B : 頭蓋外面（下面）

図 1 頭蓋底の模式困

（ ）内はその中に在るもの，×印は骨の向う側にあるあのを示す. 
できる.

中頭蓋底の構造は複雑である. 中央にはトル コ鞍があり，その中に下垂体がある。トルコ鞍 の下方には一枚の骨を介して蝶形洞がある。卜 ルコ鞍の前上方には視神経交叉があり，外側方 から外側後方には内頸動脈, 海綿静脈洞, 三叉 神経の半月神経節と 3 本の主枝（眼神経, 上顎 神経，下顎神経）の基部がある。乙の傍トルコ 鞍領域は，頭蓋底外科で手術操作が一番むずか しいところである.

三叉神経主枝の外側方は側頭下窩の上方に当 る. その外側方つまり中頭蓋底の外側部は側頭 窩の内方に当る. 中頭蓋底を外側方から開くに は，側頭窩で開頭する.

中頭蓋底の後部には側頭骨の岩様部（錐体乳 突部）があり，その中に中耳と内耳がある。耳 科学的頭蓋底外科はこの部之, 側頭骨岩様部の 後面すなわち後頭蓋底の前外側部とにおいて行 われる。

後頭蓋底の正中前部には斜台がある，斜台の 前上方には蝶形洞とトルコ鞍が，前下方には上 咽頭がある，後上方には椎骨脳底動脈之橋, 延

表 1 Surgery of the Skull Base (Sasaki, McCabe and Kirchner) ${ }^{2)}$ の主な内容

1. 前頭洞の手術

2. 頭蓋顔面切除 craniofacial resection 前頭蓋底におよぶ病変に対する手術

3.トルコ鞍の手術

経節骨法, 経鼻中隔・蝶形洞法

4. 上咽頭，蝶形洞，下垂体に対する経口蓋手術

5 . 耳下腺, 側頭下窩に対する経耳下腺手術

6. 頸静脈孔, 錐体尖, 斜台, 傍トルコ鞍部, 傍 蝶形洞部に対する側頭骨下からのアプローチ

7. 顔面神経, 内耳神経, 錐体尖真珠腫, 三叉神 経節に対する経中頭蓋窩手術

8. 内耳神経，顔面神経，小脳橋角部に対する経 迷路手術

9. 内耳道孔より内方, 脳幹の前方の部に対する 経蝸牛手術

10. 三叉神経, 舌咽神経, 迷走神経領域の痛みに 対する後迷路手術. 検査開頭にも用いられる.

11. 側頭骨岩様部の病変に対する側頭骨切除
䯣がある．斜台の外側方には側頭骨岩様部があ り，その後面に内耳道の入口がある. 内耳道の 入口の下方には頸静脈孔があり，そこから後外 上方に $\mathrm{S}$ 状静脈洞溝が走る. 斜台の後方には大 後頭孔がある。

\section{頭蓋底外科の範囲}

どの範囲の手術を頭蓋底外科と銘打つかにつ いての，はっきりした線引きは見当らない，術

表 2 Surgery of the Skull Base (Samii and Draf) ${ }^{3)}$ の主な内容

I . 前頭蓋底の手術

1. 奇形に対する手術

2. 外傷に対する手術

3. 炎症の合併症に対する手術

4. 占拠性病変に対する手術 頭蓋外からのアプローチ 頭蓋内からのアプローチ 頭蓋内・外からのアプローチの併用 (craniofacial なアプローチ)

II. 中頭蓋底の手術

1. 外傷に対する手術 側頭開頭，頸動脈海面静脈洞吻合の手術，錐 体尖と内耳道の手術，経乳突・経迷路手術

2. 炎症に対する手術

真珠腫, 静脈洞血栓, 耳性脳膿瘍, 壊疽性外 耳炎による骨髄炎などの手術

3. 下垂体の占拠性病変に対する手術

4. 中頭蓋底外側部の占拠性病変に対する手術

i . 頭蓋外外側からのアプローチ（側頭窩， 側頭下窩加ら)

ii. 頭蓋外後下方からのアプローチ（頸動脈 管，頸静脈孔から）

iii. 頭蓋内硬膜外からのアプローチ

iv . 頭蓋内硬膜内からのアプローチ

v ．頭蓋内・外からのアプローチの併用

III. 後頭蓋底の手術

1. 内耳道, 小脳橋角部の手術

i . 側頭部硬膜外からのアプローチ

ii. 経乳突・経迷路法

iii. 後頭開頭によるアプローチ

IN 、斜台の手術

1. 頭蓋外からのアプローチ

2. 頭蓋内からのアプローチ

V . 頭頸接合部の手術

VI. 顔面神経之頭蓋底外科 
者の専門領域や考え方によって，頭蓋底外科に 含まれる手術は異なるようである，表 1 は耳鼻 咽喉科・頭頸部外科医が編集した “Surgery of the Skull Base”2) と題する本の主な内容，表 2 は脳神経外科医と形成外科医が著者である，同 じく “Surgery of the Skull Base"”) と題する本 の主な内容を示す。

表 1 をみると， 2 の craniofacial resection と 6 の側頭骨下からのアプローチ以外は，耳鼻咽 喉科・頭頸部外科医が，“頭蓋底外科”などと 仰々しい名を冠することむなく，従来から行っ ていた手術，あるいはその係累の手術である.

表 2 にはより広範な手術が含まれている，注 目すべきは，脳神経外科医と形成外科医によっ て書かれたとの本の中にも，耳鼻咽喉科・頭頸 部外科医が古くから行い，発展させてきた手術 が沢山含まれていることで，大変興味深い，乙 のととは, 私達耳鼻咽喉科・頭頸部外科医が, 頭蓋底外科の分野で果す役割の広さと大きさを， はっきりと示しているのである.

側頭骨を主な術場とする耳科学的頭蓋底外科 や，下垂体に対する鼻科学的頭蓋底外科䛃 てはよく知られているので，乙こでは述べない. 本稿では前頭蓋底に達する腫瘍に対する手術に ついて，以下論説を加える.

\section{前頭蓋底の腫瘍に対する手術}

\section{1. 概 要}

前頭蓋底におよぶ鼻腔，副鼻腔，上咽頭の腫 瘍や，前頭蓋底付近に原発する腫瘍に対する基 本的な手術は，craniofacial resection 頭蓋顔面 切除である．前頭開頭下に前頭蓋底を明視下に おくとともに，顔面に皮切を加えて鼻腔，副鼻 腔，眼窩，上咽頭を明視下におく，両方加らの アプローチを併用して，病変を margin をつけ て除去する。

除去し終ったら頭蓋底を再建する，髄液漏を おこさない，無菌的な頭蓋内を，無菌的にはで きない鼻・副鼻腔から隔絶する，脳がヘルニア をおこさない支えをつくる，のが頭蓋底再建の 目的である。

\section{2 . 病変切除手術}

craniofacial resection を初めに報告したのは Smith ら4であろう. その後多くの報告があり， 今では確立された術式となっている.

頭部に冠状皮切を加え(図 2), 頭皮を帽状腱 膜とと屯に眼窩上縁まで剝離挙上する，頭蓋骨 膜は後で頭蓋底の再建に用いるので, 別に剝離 挙上し, 頭蓋骨膜弁として保存しておく. 両側 前頭開頭（図 2 ）を行って，前頭蓋窩を開く. 眼窩上骨棒 supraorbital bar に病変が浸潤して いるときには，病変部を margin をつけて切除 塊に含めるように骨を切る. 病変が浸潤してい ないときには，眼窩上骨棒を一旦取りはずして 保存しておく，前頭開頭の骨片に眼窩上縁まで 含める方法屯ある ${ }^{5}$.

腫瘍が頭蓋底骨を穿破しているときは硬膜内 で，頭蓋底骨の上面が正常のときは硬膜外で， 前頭葉を挙上し前頭蓋底を露出する．とのとき 上矢状静脈洞を結紮切断し，嗅神経を切断する。 前頭蓋底を露出する範囲は，病変の範囲による． 視神経交叉がみえるところまで前頭葉を挙上す るととができる。

顔面の皮切は病変の部位によって選択する. 上顎と眼窩も含めて広く切除するときには, 眼 窩上縁から鼻の外側を通って口唇に至る皮切

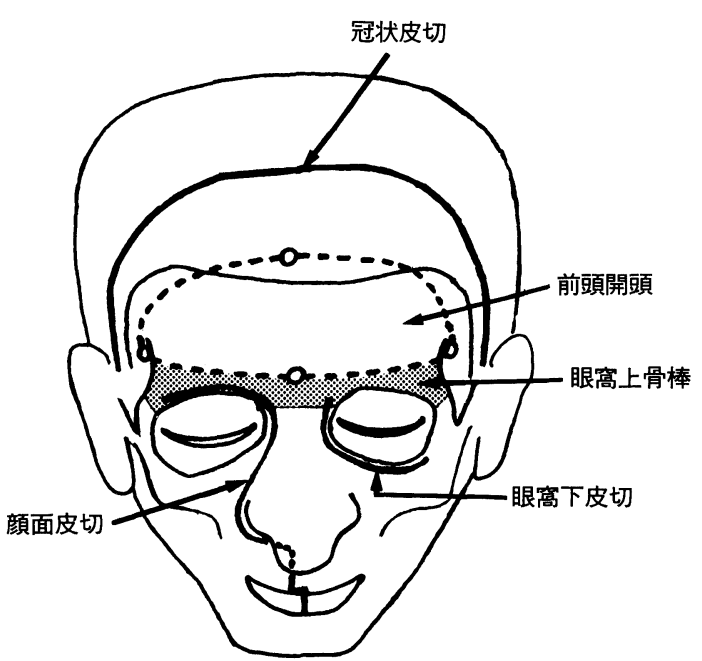

図 2 craniofacial resection に用いる皮切と骨切り 
（図 2 )を加える. 切除範囲が狭いときには，そ の一部分だけの皮切で十分である。眼窩内容摘 出（眼摘）が必要だが上顎に手術を加える必要 がないときには，眼窩下皮切を用いる，上顎や 上咽頭の手術が必要なときには, 口腔前底の粘 膜切開を併用する。 一方, 顔面皮切や粘膜切開 を必要としない場合あある. 前頭蓋底からの視 野はかなり広い6)。

頭蓋内からと顔面からの術野が得られたら， 病変をなるべく一塊として除去する. 図 3 は切 除範囲を例示する，腫瘍は入っていないが炎症 のある副鼻腔は開放し，粘膜を除去する．前頭
洞では後壁の骨も粘膜と共に除去する.

\section{3. 再 建}

脳硬膜の欠損部は, 保存硬膜, 側頭笳膜, 大 腿筋膜，頭蓋骨膜などを用いて再建する．䯣液 漏をおこさないように，欠損部を完全におおつ て water tight に縫合する.

骨の欠損部の再建については，硬い支持組織 を用いる人と，必要ないという人とがある。支 持組織としては肋軟骨, 鼻中隔軟骨, 腸骨, 開 頭のときに外した頭蓋骨の内板または外板など が用いられる．支持組織の下面すなわち鼻側面 を，頭蓋骨膜弁で打打う。硬い支持組織を置か

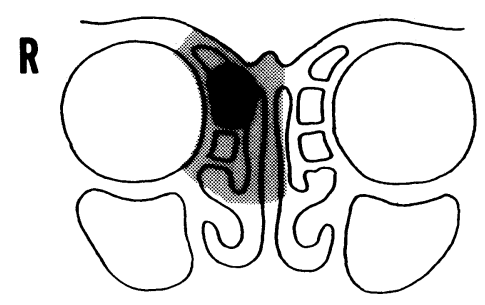

L R
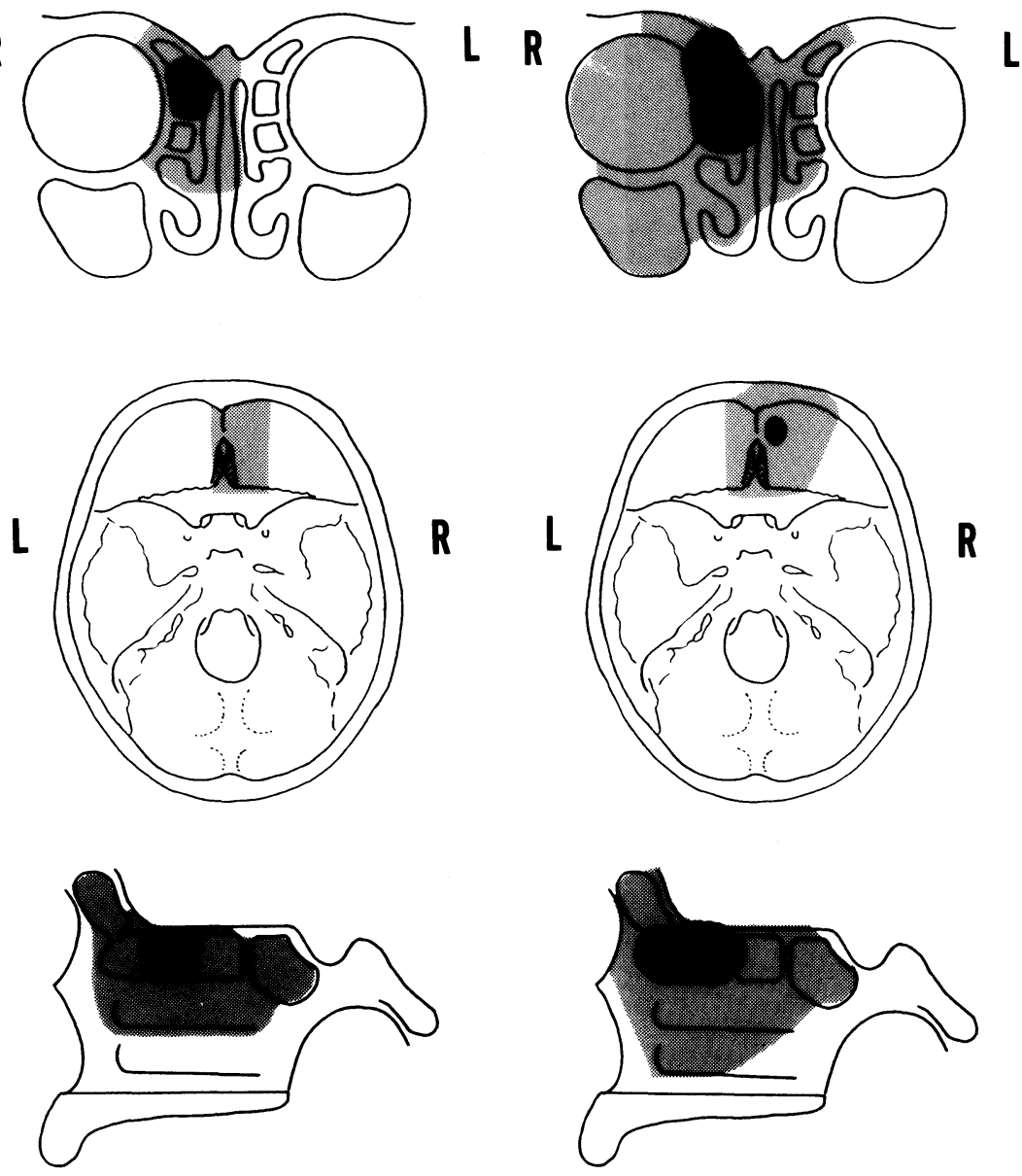

A：頭蓋底の骨を穿破していない病変

B : 頭蓋底の骨を穿破している病変

図 3 切除範囲の例

黒い部分が病変, 灰色の部分が切除範囲. 
ない場合には，再建した硬膜の鼻側に，頭蓋骨 膜弁を張る，頭蓋骨膜弁は血行がよく，感染に 対する抵抗力が強く，再建頭蓋底の鼻側に好用 される728)

頭蓋骨膜弁の鼻側に植皮をする人と，しない 人がある，植皮をしない人達は，その理由とし て痂皮がつくことをあげている，植皮をしなく ても，粘膜がはってくる.

図 4 は再建された頭蓋底を模式的に示す.

顔面の皮膚も切除したときには，筋皮弁を用 いて一期的に再建する ${ }^{9)}$ か，再発のないととを 確認して二期的に再建する．二期的再建には皮 弁または筋皮弁を用いる。

4. 術前後の処置

術中に脳を損傷なく压排するととができるよ
うにするために，〈あ膜下カテーテル留置，マ ニトールの投与，ステロイドの投与，過換気な どが行われる。

感染予防のため抗生物質を手術の前日から術 後 1 週間にわたって投与する.

術後鼻副鼻腔の創腔内にはガーゼを詰める. ガーゼは 4 〜 日後から少しずつ交換し始め, 7 ～10日後に全部のガーゼを交換する.

食事は口蓋が保存されていれば，手術の翌日 から経口的に取る.

\section{5. 私達の経験例}

私達の症例についての詳細は，原著論文とし て別に報告するが，乙こでは概要を表 3 亿示す. 今までに 7 例に手術を行った。術後の観察期間 は 1 年末満 5 例， $2 \sim 3$ 年 1 例， 5 年以上 1 例

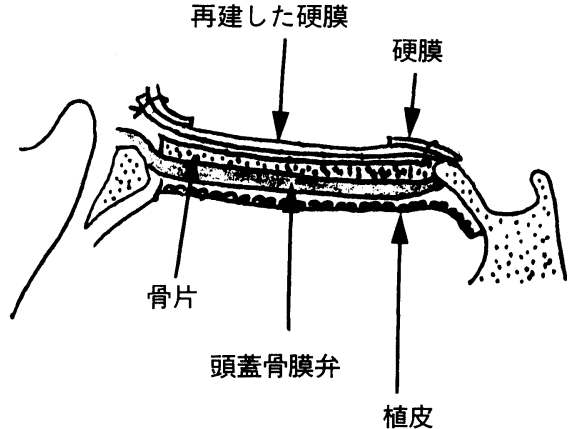

A：硬い支持組織を用いる場合

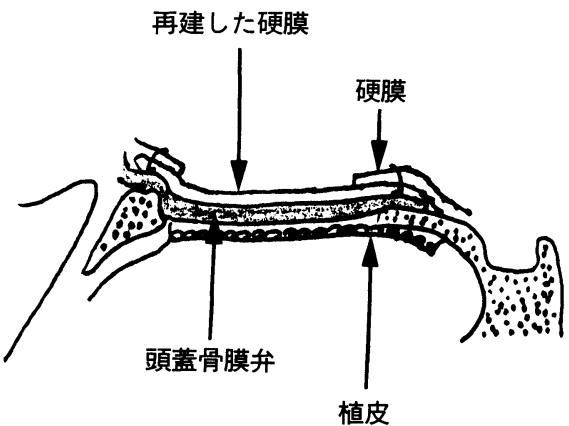

B：硬い支持組織を用いない場合

図 4 頭蓋底の再建

表 3 自験例の概要

\begin{tabular}{|c|c|c|c|c|c|c|}
\hline & 症 & 例 & 診 & 手 術 日 & 再発とその治療 & 転㷌 (1990.4.20 現在) \\
\hline 1 & 50歳 & 女 & $\begin{array}{l}\text { 前頭上洞 癌 } \\
\text { 㻞 }\end{array}$ & 1984. 5.14 & ない & $\begin{array}{l}\text { 生存, 非担癌 } \\
\text { ( } 5 \text { 年11月) }\end{array}$ \\
\hline 2 & 59歳 & 男 & $\begin{array}{l}\text { 前頭上洞 癌 } \\
\text { 病 }\end{array}$ & 1989.10. 2 & $\begin{array}{l}\text { 術後 } 2 \text { 月 } \\
\text { 眼摘, 放射線 }\end{array}$ & $\begin{array}{l}\text { 生存, 非担癌 } \\
(6 \text { 月 })\end{array}$ \\
\hline 3 & 35歳 & 男 & $\begin{array}{l}\text { 籃 骨 洞 癌 } \\
\text { 分 化 癌 }\end{array}$ & 1989. 10.23 & $\begin{array}{l}\text { 術後 } 5 \text { 月 } \\
\text { 放射線 }\end{array}$ & $\begin{array}{l}\text { 生存, 担癌治療中 } \\
(6 \text { 月 }\end{array}$ \\
\hline 4 & 75歳 & 女 & 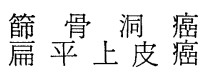 & 1989.12. 6 & ない & $\begin{array}{l}\text { 生存, 非担癌 } \\
\text { ( } 4 \text { 月) }\end{array}$ \\
\hline 5 & 46歳 & 男 & 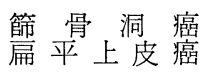 & 1990. 2.19 & ない & $\begin{array}{l}\text { 生存, 非担癌 } \\
(2 \text { 月) }\end{array}$ \\
\hline 6 & 24歳 & 男 & 嗅神経芽細胞腫 & 1988. 3. 7 & ない & $\begin{array}{l}\text { 生存, 非担癌 } \\
\text { ( } 2 \text { 年 } 1 \text { 月) }\end{array}$ \\
\hline 7 & 54歳 & 男 & 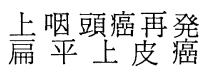 & 1990. 1.18 & ない & $\begin{array}{l}\text { 生存, 非担癌 } \\
(3 \text { 月) }\end{array}$ \\
\hline
\end{tabular}


であり, 経過の短い例が多いので，成績を論ず るのは時期尚早である。ただ，いずれも従来は 手術不能とされていたような症例であり，頭蓋 底外科によって 1 例ではあるが 5 年生存してい る例があることに，私達は大変勇気づけられて いる.

\section{むすび}

頭蓋底外科の概念と頭蓋底の外科的解剖につ いて要点を記し, 前頭蓋底の手術について説明 を行い, 私達の経験例を略述した.

頭蓋底外科の進歩によって，乙れまで手術不 能とされていた症例にも, 生きる可能性を提供 できるようになった。頭蓋底外科にはチーム・ アプローチが必要であり, 耳鼻咽喉科・頭頸部 外科医は，そのチームの一つの柱とならなけれ ばならない。多くの耳鼻咽喉科医には未経験の 分野と想像するが，一人でも多くの方達が目を 向け，参加していただきたいと切に願う次第で ある。

\section{文献}

1) 後藤光治編: 日本耳鼻咽喉科全書第 5 巻第 1 冊. 金原出版，東京・京都，1952.

2) Sasaki CT, McCabe BF and Kirchner JA (ed): Surgery of the Skull Base. JB Lippincott Company, Philadelphia, 1984.

3) Samii D and Draf W : Surgery of the Skull
Base. Springer-Verlag, Berlin, Heidelberg, New York, London, Paris, Tokyo, Hong Kong, 1989.

4) Smith RR, Klopp CT and Williams JM : Surgical treatment of cancer of the frontal sinus and adjacent areas. Cancer $7:$ 991 994, 1954.

5 ) Johns ME, Kaplan MJ, Jane JA, et al : Supraorbital rim approach to the anterior skull base. Laryngoscope $94: 1137 \sim 1139,1984$.

6 ) Blacklock JB, Weber RS, Lee Y, et al : Transcranial resection of tumors of the paranasal sinuses and nasal cavity. J Neurosurg $71: 10 \sim 15,1989$.

7) Johns ME, Winn HR, McLean WC, et al : Pericranial flap for the closure of defects of craniofacial resections. Laryngoscope $91: 952 \sim 959$, 1981.

8) Stiernberg CM, Bailey BJ, Weiner RL, et al : Reconstruction of the anterior skull base following craniofacial resection. Arch Otolaryngol Head Neck Surg $113:$ 710 712, 1987.

9) Sasaki CT, Ariyan S, Spencer D, et al : Pectoralis major myocutaneous reconstruction of the anterior skull base. Laryngoscope $95: 162 \sim 166$, 1985.

$\left(\begin{array}{l}(\text { 別刷請求先 : 平野 実 } \\ \mathbf{T} 830 \text { 久留米市旭町 } 67 \\ \text { 久留米大学医学部耳鼻咽喉科学教室}\end{array}\right)$ 